ISSN: $2455-104 X$

Impact Factor: 4.950

Volume 3,Issue 2 (July-December) 2017,122-126

Received: 21 Dec. 2017 ; Accepted: 1 Jan. 2018 ; Published: 12 Jan. 2018 ; Paper ID: IJRLS-1266

\title{
Remote Access to digital resources of Mysore University Library: a Practical Approach
}

\author{
Swapna C. ${ }^{1}$; Jayashri Jagadish, ${ }^{2}$;Venkatesha ${ }^{3}$; Manjula P. ${ }^{4}$ \\ Library Project Assistant, Mysore University Library ${ }^{1}$; \\ Assistant Librarian Mysore University Library ${ }^{2}$; \\ Assistant Librarian Mysore University Library ${ }^{3}$; \\ Project Assistant, Mysore University Library ${ }^{4}$
}

\begin{abstract}
Remote access to library's digital resources is both an expectation and need of today's user community. This paper gives a glimpse of remote access service provided by Mysore University Library, usage of digital resources \& services by using EZ Proxy through residential lines by faculty/ research scholars \& students of University of Mysore. This paper gives clear indication that by using remote access the usage of digital resources has been increased
\end{abstract}

Keywords: Remote access, EZ proxy, Digital Resources, University of Mysore.

\section{INTRODUCTION}

In this rapidly changing educational environment, popularity of On-line courses and distance education are increasing. Need of accessing information resources from their home/work place is also increasing because of time and place constraint. It has become a important task of academic libraries to give more importance on satisfying the academic needs of user whether they access information on campus or off campus.

Mysore University Library is serving the user needs since 1918 with its rich collections. The library is growing from books to e-books journals to e-journals it has never lagged behind to provide information services within the campus and off campus user also.

Mysore university library has adopted remote access technology through R3 access in the year 2010 and by 2013 Ez -proxy was adopted to provide information needs of the off campus users. This study shows that access of electronic information resources has been enhanced by introducing remote access through EZ Proxy.

\section{Remote Access / off campus access:}

\section{Definition:}

Technopedia defines remote access as "Remote access refers to the ability to access a computer, such as a home computer or an office network computer, from a remote location. This allows employees to work offsite, such as at home or in another location, while still having access to a distant computer or network, such as the office network. Remote access can be set up 
using a local area network (LAN), wide area network (WAN) or even a virtual private network (VPN) so that resources and systems can be accessed remotely".

\section{Need of Remote access in libraries:}

University library has many powerful resources/ infrastructure to serve the academic information requirements of the user community. Remote access allows user to use the information resources when the physical library is closed. User can determine whether library owns the required material before visiting the library any time any place through laptop, desktop or mobile. Many of Studies have proved that implementing remote access, the usage of library e- resources has been remarkably increased.

\section{EZ Proxy:}

There are varieties of web proxy software available for remote access, namely R3 access, Athens, etc. EZ Proxy is one of them which is commonly used by libraries. EZ proxy is software acquired by OCLC. In India this service is provided by informatics India. EZ proxy rewrites the URLs of digital resources provided by library via the VPN network from library computer terminal. EZ Proxy authenticates the remote user by IP address.

\section{Digital Resources of Mysore University Library:}

Mysore University Library's digital resources can be accessed through its e-resource portal. Library facilitates single point access to UOM purchased (licensed) resources, All e- resources subscribed through E- Shodhasindhu (earlier known as UGC INFONET) as well as Open access academic resources through its web portal.

Mysore university user community can access more than 13,000 e-journals, more than 18,000 e-books, e-thesis through Shodhaganga, more than 10 databases, Institutional repositories through e-prints from the Library web portal and UOM WEB OPAC.

Through EZ proxy off campus users were allowed to use e- resources which are available through e- Shodhasindhu and open access resources. They can use UOM WEB OPAC and e- prints. Certain resources can be accessed up to abstract level only.

\section{Objectives:}

- To know the academic year wise comparison of usage of remote access services of Mysore University Library.

- To know the usage of remote access service rendered by Mysore University Library by Science \& Social science user community.

- To know highly used Journal/ database by Faculty/ Research Scholar \& Students of Mysore University Library.

\section{Limitation:}

This study is confined to Remote access services rendered by Mysore University Library only. The usage statistics is for the academic year 2010-2016 only.

\section{Methodology:}

The required data were gathered by visiting Mysore University library website through login and password. Academic year wise usage statistics of e- resources were taken from annual report of Mysore University. 
Analysis \& Interpretation:

Table 1: year wise usage statistics of e-Resources

\begin{tabular}{|l|l|l|l|l|l|}
\hline SI No & Year & $\begin{array}{l}\text { E- Journals usage through } \\
\text { remote access }\end{array}$ & Percentage (\%) & $\begin{array}{l}\text { E- database usage Percentage (\%) } \\
\text { through remote } \\
\text { access }\end{array}$ \\
\hline 1 & 2013 & $3,15,493$ & 19.57 & 34,216 & 28.34 \\
\hline 2 & 2014 & $3,08,917$ & 19.16 & 21,954 & 18.18 \\
\hline 3 & 2015 & $3,41,402$ & 21.18 & 43,386 & 35.93 \\
\hline 4 & 2016 & $3,88,798$ & 24.12 & 21,172 & 17.53 \\
\hline Total & & $\mathbf{1 6 , 1 1 , 5 4 8}$ & & $\mathbf{1 , 2 0 , 7 2 8}$ & \\
\hline
\end{tabular}

This table depicts the usage of e-journal through remote access. The usage of E-Journals has been increased during the 4 year (2013 to 2016). whereas E- database usage has decreased in the year 2016 that is because Mysore University Library has not subscribed SciFinder database for the particular year.

Interface: Increase in the usage is evident that Faculties, Research Scholars \& Students may have been educated towards the use of E Resources through adequate orientation programmes. It is also evident from the table that E- Resources usage highly depends on Science discipline users.

Table 2: Top 10 highly used e-journals through remote access during 2013-2016

\begin{tabular}{|l|l|l|}
\hline SI No & E-Resources Name & $\begin{array}{l}\text { Usage during 2013-2016 through remote } \\
\text { access }\end{array}$ \\
\hline $\mathbf{1}$ & Science Direct & $6,99,670$ \\
\hline $\mathbf{3}$ & Wiley-Blackwell & $1,50,564$ \\
\hline $\mathbf{4}$ & Springer Link & $1,43,341$ \\
\hline $\mathbf{5}$ & JSTOR & $1,03,808$ \\
\hline $\mathbf{6}$ & American Chemical Society & 77,464 \\
\hline $\mathbf{7}$ & Royal Society of Chemistry & 63,259 \\
\hline $\mathbf{8}$ & Taylor and Francis & 54,050 \\
\hline $\mathbf{9}$ & Oxford University Press & 30,632 \\
\hline $\mathbf{1 0}$ & Nature & 12,547 \\
\hline
\end{tabular}

This table shows that highest used E-Journal is Science Direct which deals with, full-text scientific, technical and health publications, so is Wiley Blackwell which is second highest used e-journals. The table clearly explains that journals related to science subject are highly used compared to social science subject. 
Table 3: year wise usage statistics of e -resources through remote access

\begin{tabular}{|c|c|c|c|c|c|}
\hline SI No & E-Resources Name & 2013 & 2014 & 2015 & 2016 \\
\hline 1 & Science Direct & $1,47,447$ & $1,58,216$ & $1,75,914$ & $2,18,093$ \\
\hline 2 & Wiley-Blackwell & 25,240 & 24,427 & 20,328 & 80,569 \\
\hline 3 & Springer Link & 50,264 & 35,518 & 28,440 & 29,119 \\
\hline 4 & JSTOR & 31,013 & 31,451 & 23,620 & 17,724 \\
\hline 5 & $\begin{array}{l}\text { American } \\
\text { Chemical Society }\end{array}$ & 20,283 & 17,478 & 26,187 & 13,516 \\
\hline 6 & Taylor and Francis & 19,186 & 10,569 & 15,548 & 8,747 \\
\hline 7 & $\begin{array}{l}\text { Royal Society of } \\
\text { Chemistry }\end{array}$ & 4,720 & 6,053 & 32,451 & 5,411 \\
\hline 8 & $\begin{array}{l}\text { Oxford University } \\
\text { Press }\end{array}$ & 3,478 & 6,704 & 6,373 & 5,872 \\
\hline 9 & $\begin{array}{l}\text { Emerald } \\
\text { Publishing }\end{array}$ & 2,686 & 2,570 & 2,596 & 2,968 \\
\hline 10 & Nature & 1,767 & 8,226 & 1,718 & 836 \\
\hline
\end{tabular}

The above table depicts that Science Direct is the highest used E- Resources. The usage is increasing year by year during the time span of 4 years, followed by Wiley Blackwell and Springer Link. we can make out from the above table that E-resources which offers science related discipline is highly used compared to other E-resources which offers Social Science only. Though Nature publishing's are popular but the publishers have not given free access to all the research journals of their province.

\section{Findings:}

- This study shows that user community of science discipline uses the e-resources more compared to social science discipline.

- This study depict that by allowing remote access, e- resource usage has been increased.

- Open access resources of science discipline are the highly used e-resources among the other E-resources of Mysore University Library.

\section{Conclusion:}

Implementation of remote access to digital resources is obtaining popularity among the users who are geographically distance from physical library and cannot use library's resources within the library timings. Lack of ICT awareness among social science students may be one of the reasons for less usage of e resources. Hence libraries should give guidance on technical aspect, services \& resources provided by library both for on campus and off campus users by conducting orientation/ 
demonstration \& hosting a remote access guide in library web page. While purchasing the e-resources Mysore University Library has to take steps to procure social science discipline e-resources to encourage the usage.

\section{REFERENCES}

[1]. Tanmay De Sarkar , (2015),"Integrating tools to remote access facility for improved online experience", Library Hi Tech News, Vol. 32 I(7) pp. $19-23$

[2]. Cooper, Rosemarie; Dempsey, Paula R. (1998) "Remote Library Users--Needs and Expectations". Library Trends, Vol. 47 (1) pp 42-43

[3]. Sally W. Kalin, (1991), "Support Services for Remote Users of Online Public Access Catalogs", American Library Association, Vol 31 (2), pp. 197-213

[4]. Monika Mosberger, (2003) "Remote access to the collections of the Swiss National Library (SNL)", Inter lending \& Document Supply, Vol. 31(2)

[5]. http://www.webopedia.com/TERM/R/remote_access.html

[6]. http://ezproxy.uni-mysore.ac.in:2048/menu

[7]. Monika Mosberger, (2003) "Remote access to the collections of the Swiss National Library (SNL)", Inter lending \& Document Supply, Vol. 31 Iss: 2 